\title{
HONEY TRADE IN BULGARIA AND ITS IMPACT ON THE APPICULTURAL SECTOR
}

\author{
G. Aleksiev* \\ Faculty of Economics, Trakia University, Stara Zagora, Bulgaria
}

\begin{abstract}
Bulgarian apiculture undergoes a process of consolidation and concentration of production. Small producers have played an increasingly insignificant role over the last few years, and this has led to changes in trade with the industry's main product - honey. The purpose of this study is to analyze trade flows of honey from and to Bulgaria as a basis for the development of trade in the sector and its future sustainable development. In order to achieve its goal, the research should address the following tasks: to study the structure and sources of honey imports in the country; to analyze exports and trends; to assess the impact of trade flows on production in the sector.
\end{abstract}

Key words: competitiveness, sustainability, market

\section{INTRODUCTION}

Bulgarian beekeeping undergoes several transformation periods after the accession of the country to the European Union (Aleksiev and col. 2017). These changes have led to a stabilization of the sector's production potential over the past three years. Concentration of the production processes continues, and the average farm size continues to increase. At the present stage of the development of the sector, it is essential to analyze the commercial channels for the realization of the Bulgarian bee products, as well as to trace the chain of value added in the sector. Its sustainability will determine the possibilities for future development of the production of Bulgarian bee products and their processing (Otuzibrov, 2013).

In the present study, data from Agrostatistics at the Ministry of Agriculture and Food, the database of COMTARDE to the UN and FAOSTAT were used.

Methods used are analysis and synthesis, induction and deduction, statistical processing of information, etc.

*Correspondence to: Georgi Aleksiev, Faculty of Economics, Trakia University, Stara Zagora 6000, Bulgaria,georgi.alexiev@gmail.com

\section{REALIZATION OF BULGARIAN HONEY}

This inefficiency and management skills in the sector have an impact not only on production but also on the realization of the production presented in Table 1.

During the whole period surveyed, the highest realization price was reported by producers in the direct sales to the end-user and by the end of the survey period it increased to BGN 7,30 per $1 \mathrm{~kg}$. It is important to note the significant drop in the traded to end customer quantity $(21.8 \%)$ in the period 2013 - 2014, which is due to the sharp increase of the price by 1.12 $\mathrm{BGN}(18.8 \%)$, reflecting in the significant price elasticity demand for honey in the country.

By the end of the period, some of the lost positions in direct sales to the end user were recovered.

In the last year of the survey period, there was a significant increase in retailer sales, which is linked to the higher realization price compared to the sales of the processing plants and industry. 
Table 1. Realization of Bulgarian honey

\begin{tabular}{|l|l|l|l|l|l|l|l||}
\hline Years & 2011 & 2012 & 2013 & 2014 & 2015 & 2016 & 2017 \\
\hline $\begin{array}{l}\text { Direct end customer } \\
\text { sales (t) }\end{array}$ & 2365 & 2388 & 2388 & 1867 & 1712 & 1736 & 1941 \\
\hline Price (BGN) & 5.79 & 5.79 & 5.96 & 7.08 & 6.83 & 6.76 & 7.3 \\
\hline Sales to retailers (t) & 470 & 483 & 264 & 417 & 329 & 535 & 862 \\
\hline Price (BGN) food & 3958 & 3704 & 4889 & 4888 & 4534 & 3759 & 5766 \\
\hline $\begin{array}{l}\text { Sales to } \\
\text { processors (t) }\end{array}$ & 3.99 & 4.06 & 4.32 & 5.01 & 5.34 & 4.61 & 5.05 \\
\hline \begin{tabular}{l} 
Price (BGN) \\
\hline $\begin{array}{l}\text { Sales to the industry } \\
\text { t) }\end{array}$
\end{tabular} & 188 & 204 & 254 & 184 & 195 & 623 & 658 \\
\hline Price (BGN) & 3.96 & 4.07 & 4.4 & 4.86 & 5.37 & 4.62 & 4.46 \\
\hline \hline
\end{tabular}

Source: Agro-statistics of the Ministry of agriculture and food

The sales to processing plants show an increasing trend over the whole period except for 2016, mainly due to the lower purchase price. After the restoration of part of the prices in the realization of the honey in the processing plants, the quantity realized on this trade channel is increasing, reaching even record quantities $-62.4 \%$ of the marketed honey for 2017

Sales of the industry remain at the traditionally lowest level due to the lowest bidder prices offered by those market participants. In their case, manufacturers produce lower quality products or previous production cycles.

Bulgarian beekeeping has a traditionally export character due to the low levels of local consumption of bee honey in the country under $200 \mathrm{~g}$ on average per capita
(FAOSTAT), while in Western Europe the consumption exceeds $1 \mathrm{~kg}$ on average per year in countries such as Germany (FAOSTAT). Due to this export character of the sector it is necessary to analyze the realization of the Bulgarian honey on the international market, as the export of Bulgarian honey is presented in Table 2.

In the first three years of the survey period, the export of Bulgarian honey has increased sharply, with over 12.5 tons of honey being exported in 2013 at an average price of US \$ 3.62 per kilo or 5.34 BGN. These realization prices allow significant levels of profits for the processing enterprises and the wholesalers who mainly deal with the export of Bulgarian bee products.

Table 2. Export of Bulgarian natural honey

\begin{tabular}{|l|l|l|l|l|l|l|l|}
\hline & 2011 & 2012 & 2013 & 2014 & 2015 & 2016 & 2017 \\
\hline $\begin{array}{l}\text { Export } \\
\text { quantity (t) }\end{array}$ & 6853.48 & 9314.17 & 12648.87 & 10132.89 & 9784.70 & 9000.52 & 13302.04 \\
\hline $\begin{array}{l}\text { Export value } \\
(\$)\end{array}$ & 26591442 & 31763677 & 45746569 & 41626010 & 37451927 & 32465819 & 48437214 \\
\hline $\begin{array}{l}\text { Average } \\
\text { export price } \\
(\$)\end{array}$ & 3.88 & 3.41 & 3.62 & 4.11 & 3.83 & 3.61 & 3.64 \\
\hline
\end{tabular}

Source: Own calculation based on data from UN Comtrade

Significant for this period is the higher export quantity of honey from the country compared to the total production. This is due to parts of sharply increased levels of imports in 2013 nearly 3 times more than in 2012 and more than 6 times more than in 2011. This is also the first year in which exported quantities exceed the amount of honey production and imports in the country. This difference can be explained by many factors, the most significant of which are: re-export of foreign bee products; the return of unrealized quantities of Bulgarian bee 
products by foreign traders and processors and their subsequent processing and re-export; and exports of retained output from previous periods due to the nature of the product (retention of product characteristics over a longer period of time) and the rising average export price.

At the end of the survey period, the highest export levels also account for 13.3 thousand tons of honey at an average export price of $3.64 \$$ or $6.26 \mathrm{BGN}$ per kilo.

The increase in the level of exports of Bulgarian honey at the end of the period - 4.3 thousand tons in 2017 compared to 2016 is due both to increased production for the period and to retained quantities from previous periods.

The import of bee honey in the country presented in Table 3 is the main factor for the price at which Bulgarian traders manage to buy the product on international markets. The significant difference between the export and import prices of bee products creates opportunities for re-exportation in the presence of established shopping channels. The limited quantities of imports at a price difference of $\$$ 1.52 or BGN 2.61 per kilogram of honey are due to the lack of security in the beekeeping channels and the need to invest in their development.

Table 3. Import of honey in Bulgaria

\begin{tabular}{|l|l|l|l|l|l|l|l|}
\hline & 2011 & 2012 & 2013 & 2014 & 2015 & 2016 & 2017 \\
\hline $\begin{array}{l}\text { Import quantity } \\
\text { (t) }\end{array}$ & 288.604 & 655.152 & 1866.145 & 1146.380 & 1403.408 & 2009.716 & 2278.113 \\
\hline Import value (\$) & 797688 & 1603259 & 3916176 & 2549255 & 2733257 & 3758619 & 4930386 \\
\hline $\begin{array}{l}\text { Average import } \\
\text { price(\$) }\end{array}$ & 2.76 & 2.45 & 2.10 & 2.22 & 1.95 & 1.87 & 2.16 \\
\hline
\end{tabular}

Source: Own calculation based on data from UN Comtrade

The value-added chain in the sector is built based on buying, packing in industrial packages and the export of Bulgarian products to the international market. At the end of the survey period, the value-added chain for Bulgarian beekeeping is sustainable, but at low loading levels of commercial channels. This may have a negative impact on the long-term sustainability of the chain and the realization of Bulgarian bee products.

\section{PRODUCTION OF HONEY IN BULGARIA}

The production of Bulgarian honey is increasing in the period after Bulgaria's accession to the EU. In recent years, the level of production has stabilized at about 10,000 tons (Table 4).

Table 4. Honey production in Bulgaria

\begin{tabular}{|l|l|l|l|l|l|l|l|}
\hline & 2011 & 2012 & 2013 & 2014 & 2015 & 2016 & 2017 \\
\hline Apiculture productions & 21882 & 19283 & 17185 & 16143 & 17969 & 15306 & 13431 \\
\hline Bee colonies & 488950 & 461303 & 476286 & 512193 & 592987 & 610631 & 592958 \\
\hline Produced honey $(\mathrm{t})$ & 9592 & 9186 & 10065 & 9268 & 11388 & 10218 & 11807 \\
\hline
\end{tabular}

Source: Agro-statistics of the Ministry of agriculture and food

The most significant trend to be addressed during the period under review is the concentration of production in the sector. At the beginning of the period, the average number of bee families reared on a single farm was only 22.34 , and at the end of the period it reached double higher levels - 44.14 hives on average per producer. This process proves the transformation of the sector from a source of additional employment and income for a significant part of the employed in it to a basic economic activity for a number of them. This change requires maintaining and increasing the sustainability of the sector, as well as increasing its added value.

The number of bee colonies managed in the country increased by $21 \%$ over the survey period, while honey production increased by $23 \%$. This slight difference proves the lack of productivity growth in the sector despite the concentration of production. From the information analyzed so far, I can conclude that, despite the significant concentration of production in the sector, there has been no 
increase in the professionalism and efficiency of economic agents.

\section{CONCLUSION}

Bulgarian beekeeping is the only sub-sector of animal husbandry in the country, which manages to preserve and improve its position after the transformation of the agrarian sector (Kostadinova, 2011). During the survey period, the production base was developed, increasing the concentration of production. A negative role in the development of the productivity of the sector is the lack of professionalism and experience accumulated in part of the producers, which also requires specific targeted institutional support.

Over the entire period surveyed, the highest realization price was reported by manufacturers in direct sales to the consumer. In the last year of the survey period, there was a significant increase in retailer sales, which is linked to the higher realization price compared to the sales of the processing plants and industry.

The sales to processing plants show an increasing trend over the whole period except for 2016, mainly due to the lower purchase price. After the restoration of part of the price level in the realization of the honey in the processing plants, the quantity realized on this trade channel is increasing, reaching even record quantities $-62.4 \%$ of the marketed honey for 2017

During the first three years of the survey period export of Bulgarian bee honey increased sharply, with the highest export quantity of honey from the country compared to the total production being significant for this period. This is due to parts of sharply increased levels of imports in 2013 - nearly 3 times more than in 2012

At the end of the survey period, the highest levels of exports are also taken into account, which favors the future development of the sector and demonstrates the continued development of the commercial channels used by Bulgarian bee producers and processors. Bulgarian beekeeping succeeds in increasing production levels but the average productivity remains low and it is necessary to increase the qualification of the employed in the sector in order to combine the process of concentration of production with the increase of professionalism and the productivity of the Bulgarian beekeeping.

\section{REFERENCES}

1. Aleksiev G., N. Kostadinova, N. Petrova, 2017, Effects of the regional concentration of Bulgarian apiculture, Bulgarian Journal of Agricultural Science, 23 (3): 370-375. SJR-0,223

2. Otouzbirov, R. (2013). CONSUMER ENVIRONMENT IN THE COMMON EUROPEAN MARKET. Trakia Journal of Sciences, 11(3), 330.

3. Kostadinova, N. (2011). The competitiveness of Bulgarian animal husbandry and the humane attitude to animals,“. Macedonian Journal of Animal Science" published by the Institute of Animal Science in Skopje, Macedonia, 1, 231-234.

4. Агростатистика на Министерство на земеделието и храните

5. Eurostat Database

6. Comtrade Database of the United nations

7. Faostat Database 